\title{
Correction to: Alterations in bacterial communities, SCFA and biomarkers in an elderly HIV-positive and HIV-negative population in western Mexico
}

Luz A. González-Hernández,2, Mariana del Rocio Ruiz-Briseño 1,3, Karina Sánchez-Reyes', Monserrat Alvarez-Zavala1, Natali Vega-Magaña', Alvaro López-Iñiguez', Julio A. Díaz-Ramos ${ }^{4}$, Pedro Martínez-Ayala1,2, R. A. Soria-Rodriguez ${ }^{1}$, Moises Ramos-Solano ${ }^{1 *}$ and Jaime F. Andrade-Villanueva ${ }^{1,2^{*}}$

Correction to: BMC Infect Dis 19, 234 (2019) https://doi.org/10.1186/s12879-019-3867-9

Following publication of the original article [1], the authors identified an error in the labelling of Fig. 3.

in Fig. 3. The correct figure is given below.

The original article can be found online at https://doi.org/10.1186/s12879019-3867-9.

* Correspondence: biolog.moises@gmail.com; drjandradev@gmail.com ${ }^{1}$ HIV and Immunodeficiencies Research Institute, Clinical Medicine Department, CUCS-University of Guadalajara, Guadalajara, Jalisco, Mexico Full list of author information is available at the end of the article

C C The Author(s). 2020 Open Access This article is licensed under a Creative Commons Attribution 4.0 International License, which permits use, sharing, adaptation, distribution and reproduction in any medium or format, as long as you give appropriate credit to the original author(s) and the source, provide a link to the Creative Commons licence, and indicate if changes were made. The images or other third party material in this article are included in the article's Creative Commons licence, unless indicated otherwise in a credit line to the material. If material is not included in the article's Creative Commons licence and your intended use is not permitted by statutory regulation or exceeds the permitted use, you will need to obtain permission directly from the copyright holder. To view a copy of this licence, visit http://creativecommons.org/licenses/by/4.0/ The Creative Commons Public Domain Dedication waiver (http://creativecommons.org/publicdomain/zero/1.0/) applies to the data made available in this article, unless otherwise stated in a credit line to the data. 


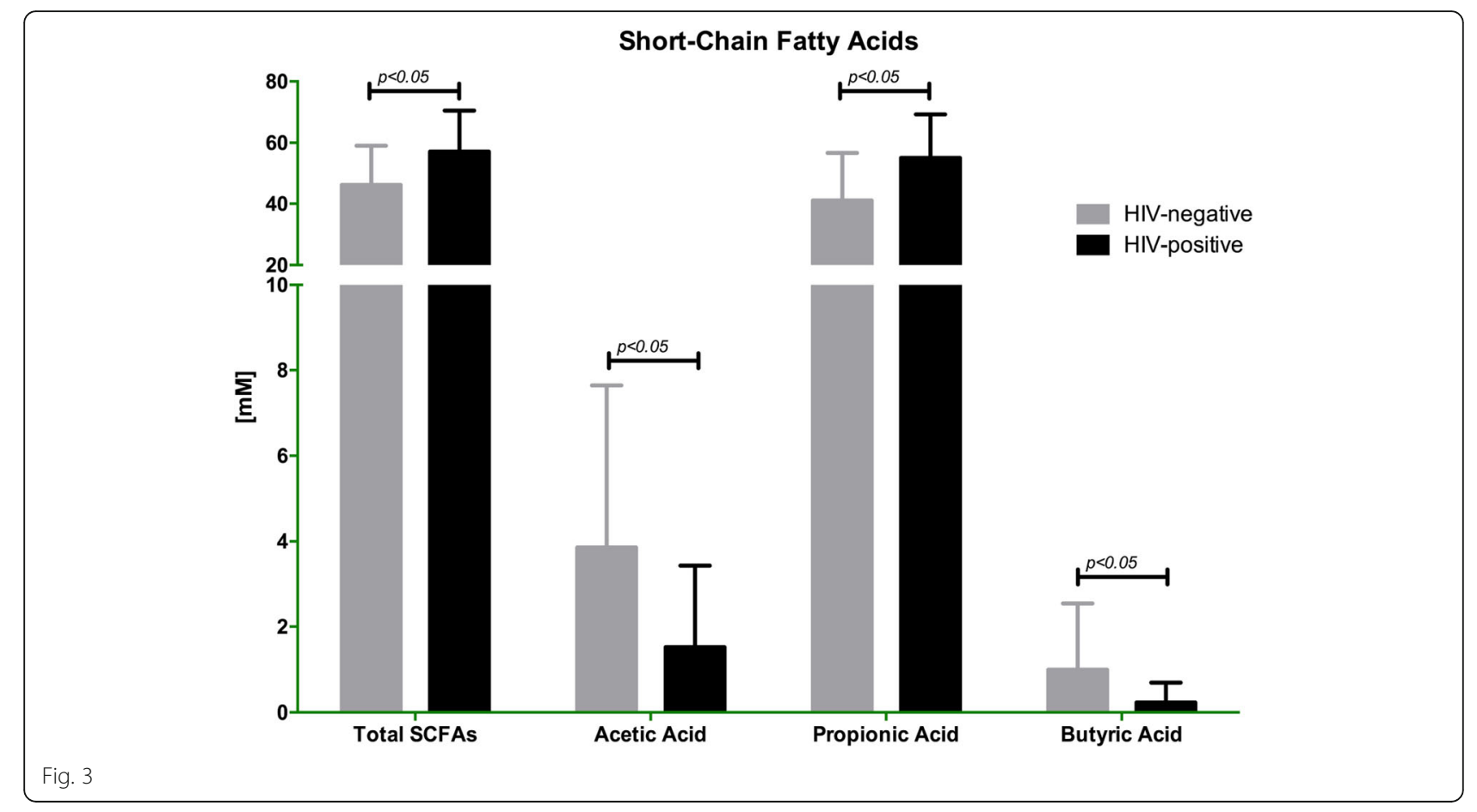

\section{Author details}

${ }^{1} \mathrm{HIV}$ and Immunodeficiencies Research Institute, Clinical Medicine

Department, CUCS-University of Guadalajara, Guadalajara, Jalisco, Mexico.

${ }^{2}$ HIV Unit Department, University Hospital "Fray Antonio Alcalde", University

of Guadalajara, Guadalajara, Jalisco, Mexico. ${ }^{3}$ Molecular Biology in Medicine

Ph. D. program, CUCS-University of Guadalajara, Guadalajara, Mexico.

${ }^{4}$ Geriatric Department, Antiguo Hospital Civil de Guadalajara "Fray Antonio

Alcalde", Guadalajara, Jalisco, Mexico.

Published online: 16 October 2020

\section{Reference}

1. González-Hernández, et al. BMC Infect Dis. 2019;19:234. https://doi.org/10. 1186/s12879-019-3867-9. 